УДК 622.234 .42

https://doi.org/10.47533/2020.1606-146X.125

MAKSAT B. KURMANSEIIT ${ }^{1,2}$, MADINA S. TUNGATAROVA ${ }^{1,2 *}$,

\author{
${ }^{1}$ Satbayev University, Almaty, Kazakhstan \\ ${ }^{2}$ Al-Farabi Kazakh National University, Almaty, Kazakhstan \\ e-mailkurmanseiit.maksat@gmail.com,m.tungatarova@satbayev.university
}

\title{
INFLUENCE OF GRAVITY EFFECT TO THE RECOVERY RATE AT URANIUM IN-SITU LEACHING
}

In-Situ Leaching is a method of extracting minerals by selectively dissolving it with a leaching solution directly in the place of occurrence of the mineral. In practice, during the development of deposits with the In-Situ Leaching method, situations arise when the solution tends to go down below the active thickness of the stratum. This may be due to geological heterogeneity of the rock or gravitational sedimentation of the solution in the rock due to the difference in the densities of the solution and groundwater. As a result of the deposition of the solution along the height, there is a decrease in the recovery of the metal located in the upper part of the geological layers.

This article examines the effect of gravity on the flow regime during the filtration of the solution in the rock. The influence of the gravitational effect on the flow of solution in the rock is studied for different ratios of the densities of the solution and groundwater without taking into account the interaction of the solution with the rock. The CUDA technology is used to improve the performance of calculations. The results show that the use of CUDA technology allows to increase the performance of calculations by 40-80 times compared to calculations on a central processing unit (CPU) for different computational grids.

Keywords: In-Situ leaching, mineral recovery, stream lines, gravity, CUDA technology, graphics processing unit (GPU), graphics processing unit (GPU).

Introduction. In-Situ Leaching (ISL) is a common method used to recover minerals in the mining industry, above all for uranium deposits such as those exploited in Kazakhstan [1-3].

ISL is the process of developing low-concentration deposits in by injecting leaching solutions through a network of injection wells and withdrawing a dissolved useful component through production wells (figure). In some fields, the deposition of the leaching solution is observed along the height and its flow into the lower layers of the rock. As a result, the mineral in the upper layers of the rock may remain unrecovered, since the leaching solution has not reached there [4]. This may be due to the presence of highly permeable areas in the geological structure of the reservoir. The lack of detailed information on the geological structure of the deposit in the interwell space does not allow to unambiguously determine whether the decrease in the level of the solution along the height is related to the geology of the reservoir. Another reason for the decrease in the level of the solution along the height may be the influence of gravitational effects due to the difference in the densities of the leaching solution and groundwater. Depending on the composition of the rock, various types of solvents can be used; in Kazakhstan, uranium is mined with sulfuric acid leaching. Moreover, the concentration of sulfuric acid in the leaching solution does not exceed 20-25 $\mathrm{g} / \mathrm{l}$ at the stage of block acidification $[3,5,6]$. In the process of leaching, along with the

\footnotetext{
* E-mail корреспондирующего автора: madina.tungatarova@gmail.com
} 
useful component, the rock components dissolve, which leads to an increase in the density of the leaching solution.

As the leaching agent density is slightly greater than groundwater density gravitational effect has to be accounted for as it may affect the flow direction. Due to this gravitational effect, the denser fluid tends to flow downward while the lighter fluid flows directly to the production well. Accounting for gravitation effect in CFD can complicate streamline simulation method, due to a need for a constant recalculation of streamlines at each iteration.

Task (problem) description and boundary conditions. To study the effect of gravity on the fluid flow in the rock, let us consider a region with uniform isotropic permeability with one hexagonal cell (Figure 2). It is assumed that the uranium ore is trapped between two impermeable layers, with thickness ${ }^{1}$ greater than 12 m, так как для меньшей мощности пласта влиянием гравитации можно пренебречь. The filtration open section for each well is about 6-8 $\mathrm{m}$ in length imposed as a Dirichlet boundary condition in the numerical simulation. Figure 2 illustrates a vertical cross-section passing along the wells 1,7,4.

For the pressure, a Van Neumann boundary condition was applied to the top and bottom impermeable layers (no flow passing through). The boundary pressure conditions applied to each vertical sides of the domain are functions of depth and chosen as constant (assuming a constant pressure along the vertical of the layer), i.e. as shown on Figure 2, the distance from the injection well to the boundary is $100 \mathrm{~m}$.

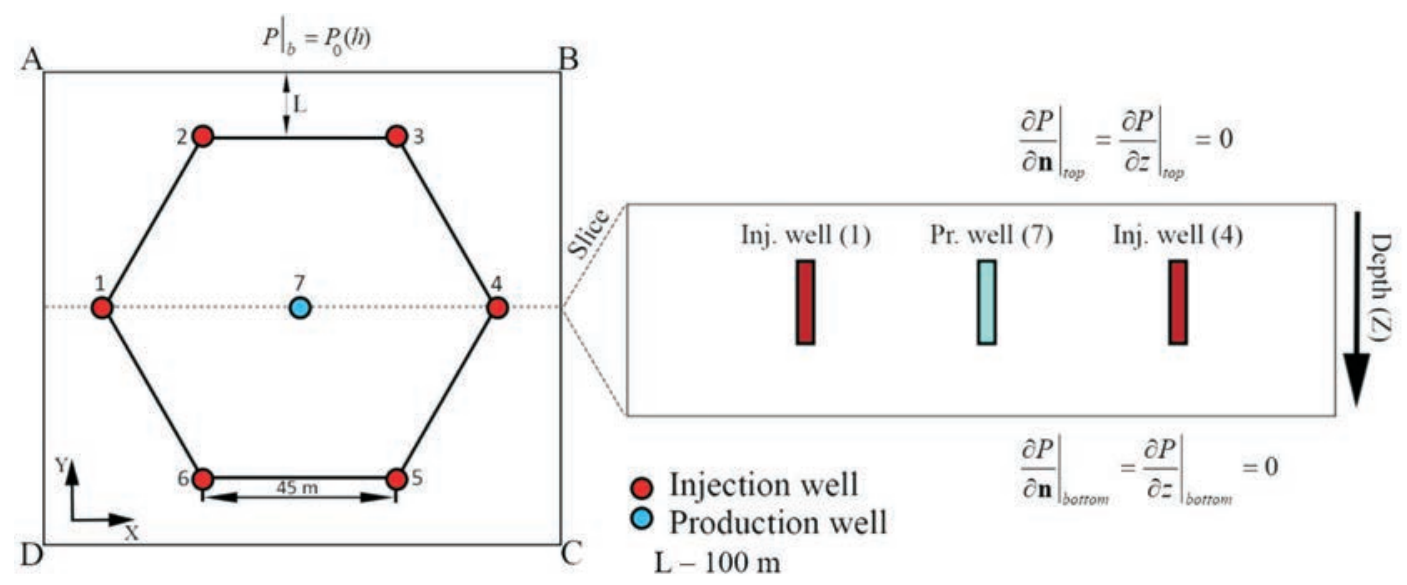

Study of gravitational effects on ISL. As the leaching agent density is slightly greater (about $\left.\rho_{l}=1.1\left[\mathrm{~g}_{\mathrm{cm}} \mathrm{cm}^{-3}\right]\right)$ than groundwater density $\left(\rho_{w}=1\left[\mathrm{~g} . \mathrm{cm}^{-3}\right]\right)$ gravitational effect has to be accounted for as it may affect the flow direction. Due to this gravitational effect, the denser fluid tends to flow downward while the lighter fluid flows directly to the production well. The acid fluid water interface (density of reagent+ water compared to pure water) is more or less tabular near the injection well, but this density contrast produces a drawdown of this interface near by the production well as shown on Figure 2. Sketch explaining the in-

${ }^{1}$ For smaller thickness the gravity effects can be neglected. 
situ leaching technique used to recover uranium in roll-fronts, a) before uranium extraction b) after uranium extraction.

Thus, during the leaching process some regions (residual zones) are not leached because of this gravitational effect, an effect often neglected in numerical simulation of the ISL process $[7,8]$. Therefore, any hydrodynamic modelling of ISL process should take into consideration the gravity forces in the Darcy Law (1):

$$
\mathbf{U}_{\phi}=-\frac{\mathbf{k}}{\mu} \cdot(\operatorname{grad}(p)+\rho \mathbf{g})
$$

where $\mathbf{U}$ is the filtration velocity (in $\mathrm{m} \cdot \mathrm{s}^{-1}$ ), $\varphi$ the porosity (notice that $\boldsymbol{v}=\boldsymbol{U} \varphi$ is the classical Darcy velocity), $\boldsymbol{k}$ the permeability tensor (in $\mathrm{m} . \mathrm{s}^{2}$ ) of porous medium ( $\boldsymbol{k}=\boldsymbol{k} \boldsymbol{I}$ for the isotropic case), $\mu$ the dynamic viscosity (in Pa.s) of fluid, $p$ the fluid pressure (in Pa), $\rho$ - the fluid density (in $\left.\mathrm{kg} \cdot \mathrm{m}^{-3}\right)$, and $\boldsymbol{g}$ the gravitational acceleration $\left(\mathrm{m} \cdot \mathrm{s}^{-2}\right)$ vector [2]. The mass Conservation Equation (2) of the injected fluid can be written as [5, 6]:

$$
\frac{\partial \rho}{\partial t}+\operatorname{div}\left(\rho \mathbf{U}_{\phi}\right)=q
$$

where $t$ is the time (in s), and $q$ the total source rate, the sum of in-flow $q_{\text {in }}$ and out-flow $q_{\text {out }}$ in a volume element: $q=q_{n}+q_{\text {out }}$ (in $\mathrm{kg} \cdot \mathrm{m}^{-3} \cdot \mathrm{s}^{-1}$ ) terms counted positively in the case of an injection of fluid, and negatively for the production of the fluid. After expansion, Eq (2) can be rewritten as:

$$
\frac{\partial \rho}{\partial t}+\phi \mathbf{U} \cdot \operatorname{grad}(\rho)+\rho \operatorname{div}(\mathbf{U} \phi)=q
$$

Assuming that fluids are incompressible $\left(\frac{d \rho}{d t}=0\right)$, it comes:

$$
\frac{\partial \rho}{\partial t}+\phi \mathbf{U} \cdot \operatorname{grad}(\rho)=0
$$

And, thus the mass balance equation Eq (3) can be simplified into the following form:

$$
\left[\rho \operatorname{div}\left(\mathbf{U}_{\phi}\right)=\mathrm{q}\right]
$$

Substituting the Darcy Law (Eq. 1) into the mass balance equation Eq (5), it comes (assuming a non-zero fluid density $\rho$ ):

$$
\operatorname{div}\left(-\frac{\mathbf{k}}{\mu} \cdot(\operatorname{grad}(p)+\rho \mathbf{g})\right)=\frac{q}{\rho}
$$

After some arithmetic, Eq. (6) can be developed as (assuming Eq. (4) stands true i.e. fluid properties are spatially stationary):

$$
\operatorname{div}\left(\frac{\mathbf{k}}{\mu} \cdot \operatorname{grad}(p)\right)+\frac{1}{\mu} \operatorname{div}(\rho \mathbf{k} \cdot \mathbf{g})=-\frac{q}{\rho}
$$




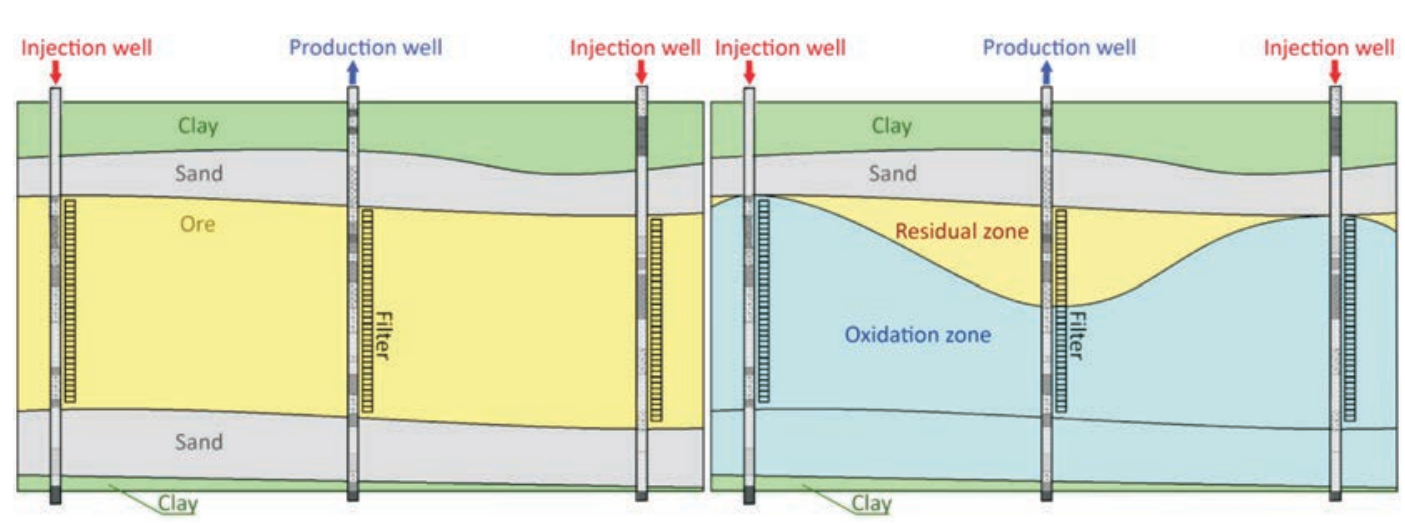

Figure 2 - Sketch explaining the in-situ leaching technique used to recover uranium in roll-fronts, a) before uranium extraction $b$ ) after uranium extraction

Eq. (7) describes the general case when permeability tensor is anisotropic. However, in sedimentary medium, the permeability tensor is often assumed to be constant in case of isotropic media or diagonal (after choosing an appropriate coordinate system). In last case, the permeability tensor can be written as:

$$
\mathbf{k}=\left[\begin{array}{ccc}
k_{x x} & 0 & 0 \\
0 & k_{y y} & 0 \\
0 & 0 & k_{z z}
\end{array}\right]
$$

where $\mathrm{k}_{i i}, i \in\{x, y, z\}$ are the permeability in the $i$ direction. In a Cartesian coordinate grid system, the gravity vector $\boldsymbol{g}$ is directed downward along the $Z$ axis, Eq. (6) can be simplified into:

$$
\operatorname{div}\left(\frac{\mathbf{k}}{\mu} \cdot \operatorname{grad}(p)\right)+\frac{1}{\mu} \mathbf{g} \cdot \operatorname{grad}\left(\rho k_{z}\right)=-\frac{q}{\rho}
$$

The scalar product of Eq. (9) can be simplified into:

$$
\operatorname{div}\left(\frac{\mathbf{k}}{\mu} \cdot \operatorname{grad}(p)\right)+\frac{g}{\mu} \frac{\partial\left(\rho k_{z}\right)}{\partial z}=-\frac{q}{\rho}
$$

Furthermore, assuming that the vertical permeability $\mathrm{k}_{z z}$ is spatial quasi constant in the layer, the derivative against $z$ can be assumed as null, and Eq. (10) can simplified into:

$$
\operatorname{div}\left(\frac{\mathbf{k}}{\mu} \cdot \operatorname{grad}(p)\right)+\frac{g k_{z}}{\mu} \frac{\partial \rho}{\partial z}=-\frac{q}{\rho}
$$

Isotropic case: when the porous medium is isotropic, the permeability tensor is diagonal $\boldsymbol{k}=k \boldsymbol{I}$ where $\boldsymbol{I}$ is the identity and $k$ the scalar intrinsic permeability; thus, Eq. (11) is still valid substituting the term $\mathrm{k}_{\mathrm{zz}}$ by the scalar permeability $\mathrm{k}$ :

$$
\operatorname{div}\left(\frac{\mathbf{k}}{\mu} \cdot \operatorname{grad}(p)\right)+\frac{g k}{\mu} \frac{\partial \rho}{\partial z}=-\frac{q}{\rho}
$$


Consequently, Eqs. (1), (4) and (11) constitute a partial differential equations system with three unknowns including the filtration velocity $\boldsymbol{U}$, the fluid density $\rho$ which depends on the acid concentration and amount of metal dissolved in the leaching fluid, and the fluid pressure $p$, respectively.

1.2 Results and discussion. Explicit iteration method was used to calculate the pressure distribution and density in the horizontal layer, since it can be easily parallelized. The velocity in each computational cell is determined from Darcy law, Pollack's method was used to determine stream lines from velocity field $[9,10]$. Streamline simulation is a determining streamlines and calculating the time it takes to move from one point to another along a path. The sum of the time of flight on the cells traversed by the particle gives the total time of travel of the particle (TOF). This method allows us to move from a threedimensional problem to several one-dimensional problems, where the dimension is the time of flight of a particle.

Equation (12) is an elliptic equation and imposes certain requirements on computing resources. The numerical experimentation was implemented in three main steps: (I) estimation of the pressure field accounting for the gravity term and the above given boundary conditions by solving Eqs. 12; (II) estimation of the velocity fields using Eqs. 1; (III) density calculation from Eqs. 4. The first step was solved on the CPU and the GPU. The CUDA parallel technology was used to accelerate the calculation time $[11,12]$.

The calculations were made with and without gravity consideration for comparison influence of gravity effects. The cross section view of pressure distribution is presented at Ошибка! Источник ссылки не найден., the top view of pressure distribution with isolines are presented at Fig. 4 (a), and streamline at Fig. 4 (b).

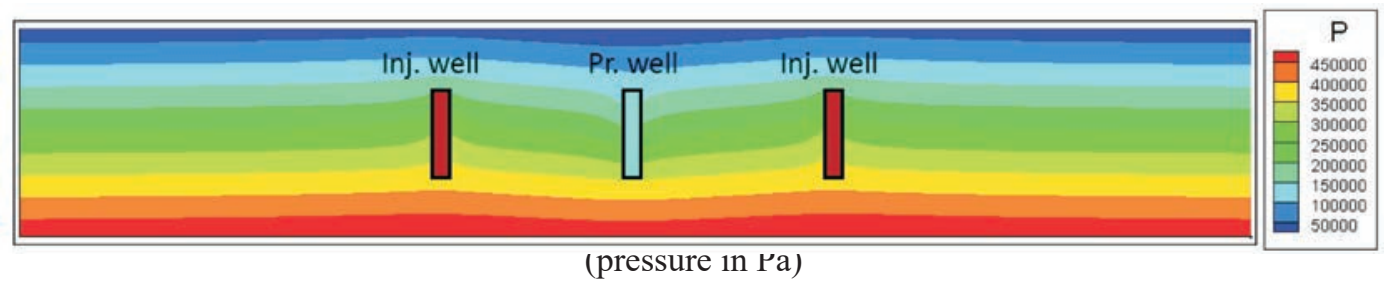

To compare computational performance calculations were conducted on CPU (Intel(R) Core(TM) i7-4790 CPU 3.6 GHz) and GPU (NVIDIA GeForce GTX 980 GPU 1.2 GHz) for various grid configurations. The calculation is performed for different mesh sizes listed in Table 1.

Table 1 - Computing time for CPU and GPU 


\begin{tabular}{|c|l|c|c|c|}
\hline № & \multicolumn{1}{|c|}{ Grid } & Computing time [s] on CPU & Computing time [s] on GPU & Ratio \\
\hline 1 & $64 \times 64 \times 64$ & 126.72 & 1.878 & 67.47 \\
\hline 2 & $128 \times 128 \times 64$ & 420.51 & 5.073 & 82.89 \\
\hline 3 & $192 \times 192 \times 96$ & 2355.36 & 48.29 & 48.77 \\
\hline 4 & $256 \times 256 \times 96$ & 4397.71 & 89.49 & 49.14 \\
\hline 5 & $256 \times 256 \times 128$ & 7249.26 & 116.15 & 62.41 \\
\hline
\end{tabular}

As shown on table 1 calculation using GPU allow to reduce the computing time an order of magnitude compared to the use of the CPU.
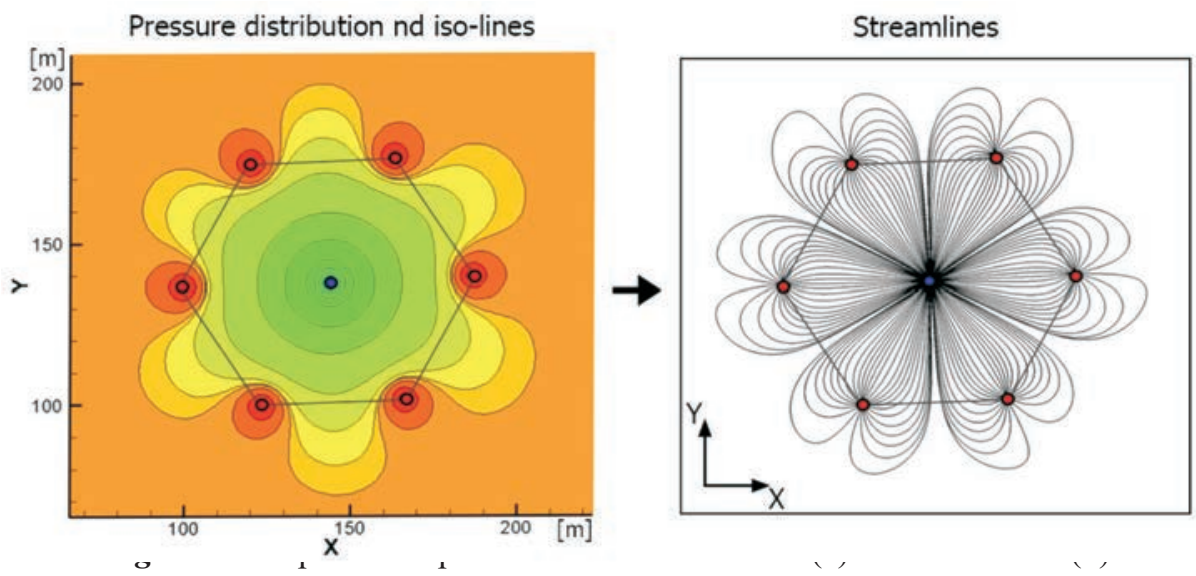

To determine the effect of gravity, three different values of the density of the injected reagents $\left(1010,1015,1100\left[\mathrm{~kg} \cdot \mathrm{m}^{-3}\right]\right)$ were considered. Density distributions in the rock were obtained and streamlines from the injection wells to the pumping well were plotted for the indicated cases (Fig. 5). The results show that with an increase in the density of the solution, the influence of the gravitational effect increases, the flow descends along the height, the streamlines lose their symmetry relative to the midline of the filters.

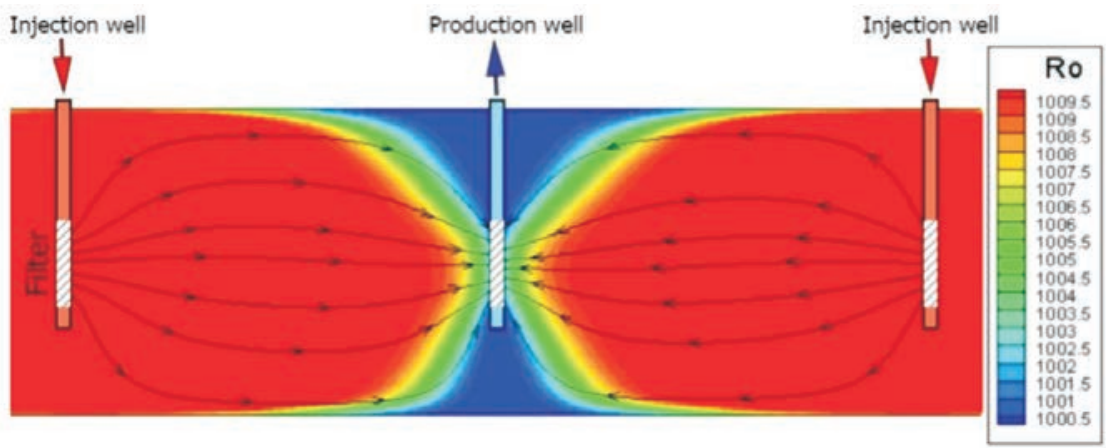




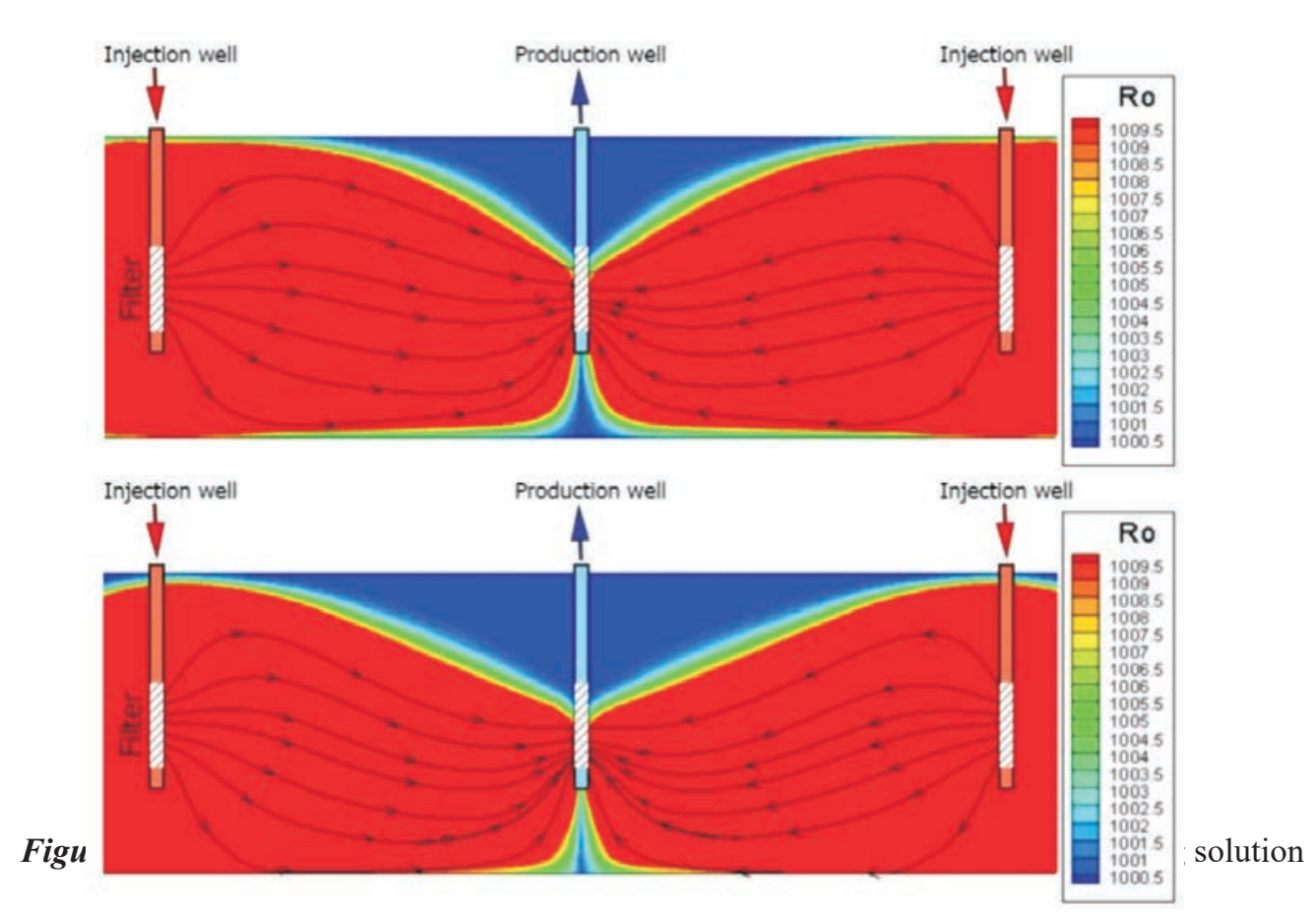

To analyze the symmetry of the streamline, the average height between streamlines along the wells was determined (Figure 6) for different values of the density of the leaching solution. As can be seen in the figure, as the density of the reagent increases, the middle streamline drops below, thereby showing that the streamlines are losing their symmetry.

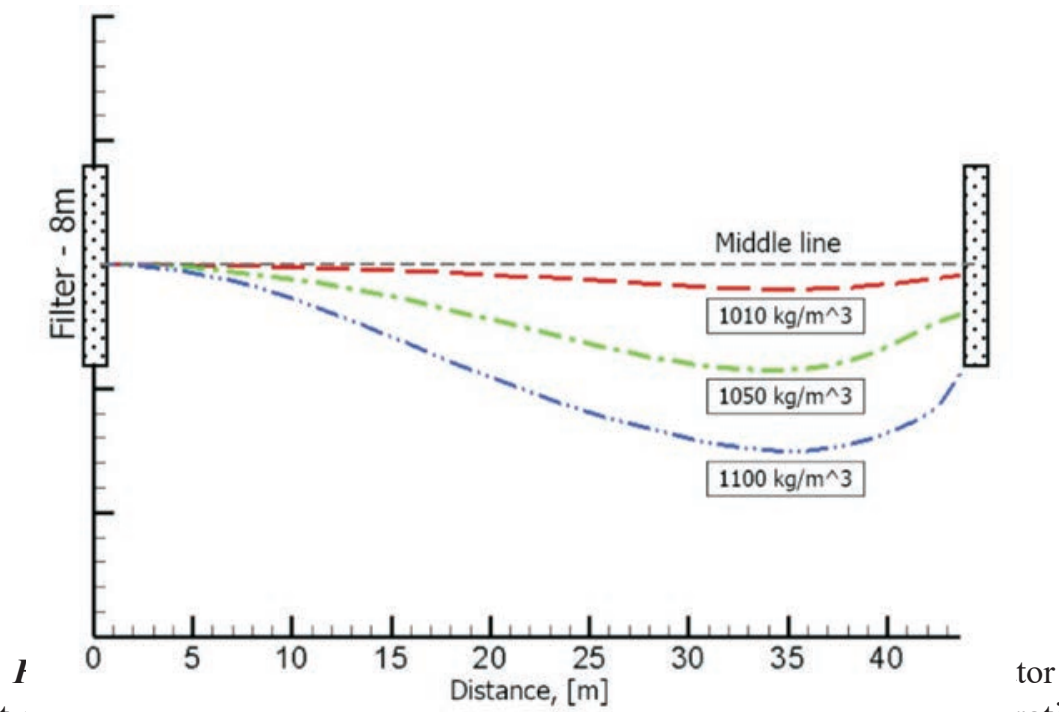

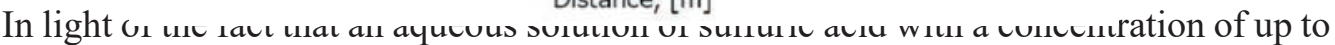
20-25 g/l is used for the leaching solution at uranium deposits, its solution density will be 
about $1010 \mathrm{~kg} \cdot \mathrm{m}-3$ [2, 3]. Dissolution of the mineral and rock component with the leaching solution will not lead to such a significant increase in the density of the solution, i.e. the gravitational effect due to the density difference can be neglected. Thus, the decrease in the height of the leaching solution at the fields is largely due to the existing heterogeneity in the geological structure of the field.

Conclusion. Accounting for gravity effect can seriously change the way a horizontal layer is being oxidized, and consequently leached during an ISL process. In present work this change has been demonstrated by conducting hydrodynamic calculations using a parallelized CUDA - based numerical solver. When gravity effects are accounted for, consequent changes in the spatial distribution of the density (and so in acid concentration) around the injection wells are observed, and lead to a very different pressure gradient field. As a consequence, the way leaching solution flows in the stratum is changed. Resource intensive pressure calculations had to be solved on each density changing, which leads to increasing calculation times. Therefore, CUDA parallel technology was successfully used in each step in order to accelerate these calculations. A speed factor of 40 to 80 is thus obtained, depending on the mesh size used.

Future work requires the implementation of the chemical kinetics reactive transport, planned to be solved along the streamlines, in order to estimate the amounts of uranium left over in the underground. Modeling of such process with account for the gravity effect can help in determining the optimal well pattern and their filtration zone positions for a most cost effective production.

Acknowledgments. The work was supported by the Ministry of Education of Kazakhstan through the project of grant financing AP08051929.

\section{REFERENCES}

1 ZHivov V.L., Bojcov A.V., SHumilin M.V. Uran: geologiya, dobycha, ekonomika. - M.: Atomizdat, 2012. - 304 s. [Zhivov V.L., Boytsov A.V., Shumilin M.V. Uran: geologiya, dobycha, ekonomika. - M.: Atomizdat, 2012. - 304 p.]

2 Brovin K.G., Grabovnikov V.A., SHumilin M.V., YAzikov V.G. Prognoz, poiski, razvedka i promyshlennaya ocenka mestorozhdenij urana dlya otrabotki podzemnym vyshchelachivaniem. - Almaty: Galym, 1997. - 248 s. [Brovin K.G., Grabovnikov V.A., Shumilin M.V., YAzikov V.G. Prognoz, poiski, razvedka i promyshlennaya otsenka mestorozhdeniy urana dlya otrabotki podzemnym vyshchelachivaniyem. - Almaty: Galym, 1997. - 248 p.]

3 Gromov B.V. Vvedenie v himicheskuyu tekhnologiyu urana. - M.: Atomizdat, 1978. - $336 \mathrm{~s}$. [Gromov B.V. Vvedeniye v khimicheskuyu tekhnologiyu urana. - M.: Atomizdat, 1978. - 336 p.]

4 Poezzhaev I.P., Abdulmanova D.M. Issledovanie gidrodinamiki processa vyshchelachivaniya na nekotoryh ob"ektah PSV // Sbornik dokladov 3-ej mezhdunarodnoj nauchno-prakticheskoj konferencii «Aktual'nye problemy uranovoj promyshlennosti». - Almaty, 2004. - S. 163-165. [Poezzhaev, I.P., Abdul'manova, D.M. Issledovanie gidrodinamiki processa vyshhelachivanija na nekotoryh obektah PSV // Sbornik dokladov 3-ei mezhdunarodnoj nauchno-prakticheskoj konferencii «Aktual'nye problemy uranovoi promyshlennosti ». - Almaty, 2004. - P. 163-165]

5 Mamilov V.A., Petrov R.P., SHushaniya G.R. Dobycha urana metodom podzemnogo vyshchelachivaniya. - M.: Atomizdat, 1980. - 248 c. [Mamilov V.A., Petrov R.P., Shushaniya G.R. Dobycha urana metodom podzemnogo vyshchelachivaniya. - M.: Atomizdat, 1980. - 248 p.]

6 Beleckij V.A., Bogatkov JI.K., Volkov N.I. Spravochnik po geotekhnologii urana / Pod red. Skorovarova D.I. - M.: Energoatomizdag, 1997. - 602 c. [Beletskiy V.A., Bogatkov JI.K., Volkov 
N.I. Spravochnik po geotekhnologii urana / Pod red. Skorovarova D.I. - M.: Energoatomizdag, 1997. -602 p.]

7 Barenblatt G.I. Dvizhenie zhidkostej i gazov v prirodnyh plastah. - M.: Nedra, 1984. - 288 s. [Barenblatt G.I. Dvizheniye zhidkostey i gazov v prirodnykh plastakh. - M.: Nedra, 1984. - 288 p.]

8 Danaev N.T., Korsakova N.K., Pen'kovskij V.I. Massoperenos v priskvazhinnoj zone i elektromagnitnyj karotazh plasta. - Almaty: Қаzақ universiteti, 2005. - 180 s. [Danayev N.T., Korsakova N.K., Pen'kovskiy V.I. Massoperenos v priskvazhinnoy zone i elektromagnitnyy karotazh plasta. - Almaty: Kazakh universitetí, 2005. - 180 p.]

9 Datta-Gupta, A., King, M.J. Streamline Simulation: Theory and Practice / SPE Textbook Series. - Vol. 11. - 2007. -394 p.

10 Pollock, D. W. Semi-analytical Computation of Path Line for Finite Difference Models // Ground Water. - Vol. 26(6). - 1988. - P. 743-750.

11 Imankulov T.S., Daribayev B., Comparative analysis of parallel algorithms for solving oil recovery problem using CUDA and OPENCL // International Journal of Nonlinear Analysis and Applications. - Vol. 12 (1). - 2021. - P. 351 - 364

12 Kim H.-S., Wu S. Chang L.-W. A scalable tridiagonal solver for GPUs // Proceedings of the International Conference on Parallel Processing. - 2011. - P. 444-453 (10.1109/ICPP.2011.41)

\section{М. Б. КҰРМАНСЕЙІТ ${ }^{1,2}$, М. С. ТУНГАТАРОВА ${ }^{1,2}$}

${ }^{1}$ Сатпаев университет, Алмать Казахстан

${ }^{2}$ Казахский национальный университет им. аль-Фараби, Алматы, Казахстан

\section{ВЛИЯНИЕ ГРАВИТАЦИОННЫХ ЭФФЕКТОВ НА ИЗВЛЕЧЕНИЕ УРАНА ПРИ ДОБЫЧЕ МЕТОДОМ ПОДЗЕМНОГО ВЫЩЕЛАЧИВАНИЯ}

Подземное выщелачивание - способ добычи минералов путем их селективного растворения выщелачивающим раствором непосредственно на месте залегания минерала. На практике при разработке месторождений методом подземного выщелачивания возникают ситуации, когда раствор опускается по мощности пласта. Это может быть связано с геологической неоднородностью породы или гравитационного осаждения раствора в породе за счет разности плотностей раствора и грунтовых вод. В результате осаждения раствора по высоте происходит снижение извлечения металла, расположенного в верхней части геологических слоев.

В данной статье исследуется влияние гравитации на режим течения при фильтрации раствора в породе. Влияние гравитационного эффекта на течение раствора в породе исследуется для различного отношения плотностей раствора и грунтовых вод без учета взаимодействия раствора с породой. Для повышения производительности расчетов применяется технология СUDA. Результаты показывают, что применение технологии СUDA позволяет повысить производительность расчетов в 40-80 раз по сравнению с вычислениями на иентральном прочессоре (CPU) для различной расчетной сетки.

Ключевые слова: подземное выщелачивание, извлечение минерала, линии тока, гравитация, технология CUDA, графический прочессор, изентральный прочессор. 


\section{М. Б. ҚҰРМАНСЕЙІТ ${ }^{1,2}$, М. С. ТУНГАТАРОВ $A^{1,2}$}

${ }^{1}$ Сатпаев университеті, Алматы,Қазақстан

²л-Фараби атындавы Қазақұ ұлттық университеті, Алматы, Қазақсттан

\section{УРАНДЫ ЖЕР АСТЫ ШАЙМАЛАУ ӘДІСІМЕН ӨНДІРУ КЕЗІНДЕ ГРАВИТАЦИЯ ЭФФЕКТІСІНІН ӘСЕРІ}

Жер асты шаймалау - тікелей минерал пайда болган жерде шаймалау арқыль селективті еріту, пайдаль құазбаларды алу әдісі туралы айтылады. Сілтісіздендіру кезінде ерітінді кенді жыныспен әрекеттесуі ерітіндінің тызыздызының өзгеруіне әкеледі. Ерітінді мен жер асты суының тызыздықтарының айырмашылыгы жавдайында жыныставы ерітіндінің авысына гравитациялық әсер басым бола бастайды. Бұдан, ерітіндінің тывыздывы жер асты суларының тызызздывынан жогары болса, ерітінді жыныста құозгалуы биіктік бойынша авынның деңцейін төмендеуіне әкеледі, нәтижесінде жовары бөлігінде орналасқан металва ерітінді жетпеуінен өндіруін төмендеуіне әкеледі.

Бұлмақаладажыныставыерітінді фильтрачиякезіндегравитачиякүшініңавынрежимінеәсері зерттеледі. Жыныс пен ерітінді арасындавы әрекеттесуін есепке алмай тек тызызздықтарының әр түрлі құатынаставы жавдайда гравитация эффектісі авынва әсері зерттелді. Есептеулердің орындалуын жақссарту үшін CUDA технологиясы қолданылды. Нәтижелер CUDA технологиясын қолдану орталық процессор (CPU) арқылы есептеулермен салыстырданда есептеу өнімділігі 4080 есе арттыруга мүмкіндік беретінін көрсетті.

Түйін сөздер: жерасты шаймалау, минералды өндіру, авын сызықтары, гравитация, CUDA технология, графикалық процессор, орталық процессор. 